\title{
PENGGUNAAN MEDIA GAMBAR DALAM MENINGKATAN MOTORIK HALUS PADA ANAK KELAS 1 DI MI AR RAHMAH KARAWANG
}

\author{
Tia Latifatu Sadiah \\ Fakultas Keguruan dan Ilmu Pendidikan \\ Universitas Buana Perjuangan Karawang \\ Tia.latifatu@ubpkarawang.ac.id
}

\begin{abstract}
The use of media images in order to increase fine motor in grade 1 class 1 in MI Ar Rahmah Karawang this is one way for children to be more eager to follow the learning in MI Ar Rahmah because the media images can develop aspects learners learn, namely fine motor aspects, creativity, psychosocial, and physiological, in the child's learning activities will be stimulated by the teacher, identify the classification, and evaluate. Based on the things mentioned above, in particular, it is also questionable how the use of image media in order to increase fine motor in grade 1 class 1 In MI Ar Rahmah it goes and in other words whether the development of fine motor through the picture can improve the learning aspect students in MI Ar Rahmah.
\end{abstract}

Keywords: media images, fine motoric

\begin{abstract}
Abstrak: Penggunaan media gambar untuk meningkatkan motorik halus di kelas 1 kelas 1 di MI Ar Rahmah Karawang inilah salah satu cara agar anak lebih bersemangat mengikuti pembelajaran di MI Ar Rahmah karena media gambar dapat mengembangkan aspek belajar peserta didik, yaitu Aspek motorik halus, kreativitas, psikososial, dan fisiologis, dalam kegiatan belajar anak akan dirangsang oleh guru, identifikasi klasifikasi, dan evaluasi. Berdasarkan hal tersebut di atas, khususnya, juga dipertanyakan bagaimana penggunaan media gambar dalam rangka meningkatkan motorik halus di kelas 1 kelas 1 di MI Ar Rahmah ia pergi dan dengan kata lain apakah perkembangan motorik halus melalui gambar dapat memperbaiki aspek pembelajaran siswa di MI Ar Rahmah.
\end{abstract}

Kata kunci: media gambar, motorik halus 


\section{PENDAHULUAN}

Pendidikan mempunyai perencanaan yang sangat menentukan bagi perkembangan dan perwujudan diri individu, yaitu manusia yang beriman dan bertaqwa kepada Tuhan Yang Maha Esa berbudiluhur, berkepribadian, disiplin, bekerja keras, tangguh, bertanggung jawab, bersikap dan berprilaku inovatip dan kreatif.

Indikator sumber daya manusia yang berkualitas, satu diantaranya adalah munculnya produk kreatif seseorang. Produk kreatif akan muncul bila mana ada motivasi baik motivasi intrinsik maupun ekstrinsik disertai komitmen yang tinggi untuk mencapai prestasi serta adanya wahana yang memungkinkan munculnya kreativitas. Semakin tinggi potensi kreativitas seseorang dan didukung keterbukaan wahana untuk mengekspresikan kreativitasnya, maka semakin terbuka pulalah peluang munculnya produk kreatif.

Tujuan pendidikan pada umumnya ialah menyediakan lingkungan yang memungkinkan anak kelas 1 untuk mengembangkan bakat dan kemampuanya secara optimal, sehingga anak kelas 1 dapat mewujudakan dirinya dan berfungsi sepenuhnya, sesuai dengan kebutuhan pribadinya dan kebutuhan masyarakat. Setiap orang mempunyai bakat dan kemampuan yang berbeda-beda. Pendidikan bertujuan untuk memandu, membina, memupuk, mengemengembangkan, dan meningkatkan bakat. Program pendidikan nasional, secara umum, meliputi tiga tahapan yaitu pendidikan dasar, pendidikan menengah dan pendidikan tinggi. Pendidikan dasar dimulai ketika anak menginjak usia enam tahun atau lebih. Pendidikan Dasar merupakan bentuk pendidikan fakultatif dalam rangka mempersiapkan anak-anak masuk ke pendidikan yang lebih tinggi. Sekalipun bersifat fakultatif pendidikan di MI Ar Rahmah, tetap diakui eksistensinya sebagai suatu jenis pendidikan yang penting karena keberadaanya itu merupakan basis bagi pendidikan selanjutnya, terutama dalam bidang pendidikan kreatif.

Pendidikan dasar di MI Ar rahmah didirikan sebagai usaha mengembangkan seluruh segi kepribadian anak kelas 1 dalam rangka menjembatani pendididkan dalam keluarga ke pendidikan yang lebih tinggi. MI Ar Rahmah merupakan salah satu bentuk pendidikan prasekolah adalah pendidikan untuk membantu 
pertumbuhan dan perkembangan jasmani dan rohani anak didik diluar lingkungan keluarga sebelum memasuki pendidikan dasar.

Kegiatan di MI Ar Rahmah tentunya sangat berbeda dengan kegiatan pembelajaran di Sekolah Dasar lain. Kegiatan di MI Ar Rahmah dilaksanakan dengan cara belajar sesuai dengan prinsip Sekolah dasar, hal ini merupakan cara yang paling efektif, karena dengan belajar anak dapat mengembangkan penggunaan media gambar dalam rangka peningkatan motorik halus pada anak kelas $1 \mathrm{di} \mathrm{MI} \mathrm{Ar}$ Rahmah , termasuk perkembangan motorik halus anak, meningkatkan penalaran dan memahami keberadaan lingkungan, terbentuk imajinasi, mengikuti imajinasi, mengikuti peraturan, tata tertib dan disiplin. Dalam kegiatan belajar anak menggunakan seluruh aspek pancainderanya.

Kegiatan pembelajaran di MI Ar Rahmah merupakan hal yang menyenangkan, kegiatan belajar di MI Ar Rahmah Desa Bengle adalah belajar yang kreatif dan menyenangkan karena penerapan gambar untuk menstimulasi anak kelas 1, dengan demikian anak tidak akan canggung lagi menghadapi cara pembelajaran dijenjang berikutnya. Dalam memberikan kegiatan belajar pada anak kelas 1 harus diperhatikan kematangan atau tahap perkembang kreativitas anak kelas 1, Alat belajar atau alat bantu, dan tehnik yang digunakan yaitu dengan cara menstimulasi anak kelas 1 melalui gambar, serta waktu dan tempat yang sudah di tentukan.

Penggunaan media gambar dalam rangka peningkatan motorik halus pada anak kelas 1 kelas 1 Di MI Ar Rahmah Karawang ini merupakan salah satu cara agar anak lebih bersemangat mengikuti pembelajaran di MI Ar Rahmah karena media gambar dapat mengembangkan aspek pembelajarananak didik, yakni aspek motorik halus, kreativitas, psikososial, dan fisiologis, dalam kegiatan pembelajaran anak akan di beri stimulasi oleh guru, mengidentifikasi melakukan klasifikasi, dan melakukan evaluasi.

Berdasarkan pada hal-hal tersebut di atas, secara khusus, patut dipertanyakan pula bagaimana penggunaan media gambar dalam rangka peningkatan motorik halus pada anak kelas 1 kelas 1 Di MI Ar Rahmah itu berlangsung dan dengan kata lain apakah pengembangan motorik halus melalui gambar dapat meningkatkan aspek pembelajaran anak didik di MI Ar Rahmah. 
MI Ar Rahmah Kabupaten Karawang, khususnya kelas 1, dalam pembelajaran dengan teknik melalui gambar dari prestasi akademik sudah baik. Jumlah anak didik kelas 1 adalah 18 anak, dengan latar belakang sosial ekonomi orang tua mampu dan sudah sadar akan pendidikan anaknya, sehingga setiap anak didik memiliki berbagai perlengkapan untuk menunjang belajarnya di Sekolah.

Berdasarkan pada hal-hal tersebut di atas, secara khusus, patut dipertanyakan pula bagaimana pengggunaan media gambar di MI Ar Rahmah itu berlangsung dan dengan kata lain apakah penerapan pembelajaran melalui gambar dapat meningkatkan aspek pembelajaran dan kreativitas anak didik di MI Ar Rahmah .

\section{METODE PENELITIAN}

Pendekatan penelitian dilakukan untuk mengungkapkan penggunaan media gambar dalam meningkatkan motorik halus pada anak kelas 1 di PAUD "MI Ar rahmah" Desa Kondang Jaya Kecamatan Karawang Timur Kabupaten Karawang, ini dilakukan dengan pendekatan kualitatif dan metode deskriptif. Pendekatan kualitatif ini dianggap lebih sesuai dengan alasan sebagai berikut : 1) Lebih tepat guna mudah berhadapan dengan kenyataan, 2) Menyajikan secara langsung hakikat hubungan antara penelitian denga responden lebih peka dan lebih dapat menyesuaikan diri, 3) Dengan pendekatan kualitatif, penelitian sebagai instrumen harus berupa menerapkan rambu-rambu, yaitu penelitian harus memahami latar belakang penelitian, mempersiapkan diri, meyakini hubungan dilapangan dan melibatkan dengan mengumpulkan data (Lexi Moleong, 2004:102). Pendekatan kualitatif ini merupakan pendekatan yang menghasilkan data deskriptif berupa katakata tertulis atau lisan dari orang-orang dan perilaku yang dapat diamati oleh sebab itu dalam penelitian ini, peneliti terlibat langsung dengan subjek diteliti dengan tujuan penelitian.

Dengan menggunakan metode deskriptif, yaitu membicarakan, memecahkan masalah yang terjadi pada masa sekarang, pada saat penelitian dilakukan. Sebagaimana yang tercantum dalam diktat metode penelitian sosial. Penelitian deskriptif adalah penyelidikan yang dilakukan untuk mendapatkan fakta-fakta dengan dilakukan interpretasi data secara cermat. Bertujuan untuk menggambarkan 
atau melukiskan seseorang, lembaga atau masyarakat tertentu pada saat sekarang, berdasarkan faktor-faktor yang nampak saja dalam situasi yang sedang berjalan.

Dengan demikian dengan penelitian ini, peneliti berupaya untuk mencari dan menskripsikan data dari kasus yang terjadi di lapangan secara alami berkaitan dengan penggunaan media gambar dalam meningkatkan motorik halus pada anak kelas 1 di "MI Ar rahmah" Desa Kondang Jaya Kecamatan Karawang Timur Kabupaten Karawang

\section{HASIL DAN PEMBAHASAN}

Dalam setiap kegiatan belajar mengajar bagian proses pembelajaran merupakan bagian terpenting. Pembelajaran adalah suatu kombinasi yang tersusun meliputi unsure-unsur manusiawi, material, fasilitas, perlengkapan, dan prosedur yang saling mempengaruhi untuk mencapai tujuan pembelajaran. Manusia terlibat dalam sistem pembelajaran yang terdiri dari siswa, sumber belajar. Material meliputi buku-buku, papan tulis, fotografi, slide dan film, audio dan video tape. Fasilitas dan perlengkapan terdiri dari ruangan kelas, perlengkapan audio visual juga komputer. Prosedur meliputi jadwal, metode dll.

Pembelajaran untuk PAUD merupakan proses interaksi antara anak, orang tua, guru dalam suatu lingkungan untuk mencapai tujuan yang diinginkan. Interaksi yang dibangun tersebut merupakan faktor yang mempengaruhi tercapainya tujuan pembelajaran yang akan dicapai. Hal ini disebabkan interaksi tersebut mencerminkan suatu hubungan diantara anak akan memperoleh pengalaman yang bermakna, hingga proses pembelajaran akan berjalan dengan lancar.

Pada hakekatnya anak belajar sambil belajar, oleh karena itu pembelajaran pada anak kelas 1 pada dasarnya adalah belajar. Sesuai dengan karakteristik anak kelas 1 yang bersifat aktif dalam melakukan berbagai eksplorasi terhadap lingkungannya, maka aktivitas belajar merupakan bagian dari proses pembelajaran. Pembelajaran diarahkan pada pengembangan dan penyempurnaan potensi kemampuan yang dimiliki seperti kemampuan berbahasa, sosio-emosional, motorik dan intelektual. Untuk itu pembelajaran pada anak kelas 1 harus dirancang agar anak merasa tidak terbebani. Agar suasana belajar tidak memberikan beban dan membosankan anak, 
suasana belajar perlu dibuat secara alami, hangat dan menyenangkan. Aktivitas belajar yang memberi kesempatan pada anak untuk mengeksplor kreatifitas dan imajinasi yang dimiliki anak merupakan hal yang diutamakan. Selain itu karena anak merupakan individu yang unik dan sangat variatif, maka unsur variasi individu dan minat anak juga perlu diperhatikan.

Untuk mencapai tujuan pembelajaran seperti yang dikemukakan diatas, diperlukan metode yang dapat mengembangkan kreativitas anak, mengembangkan gerak motoriknya, emosi, dan juga pengembangan imajinasi anak. Metode yang dipilih adalah metode yang dapat menggerakan anak untuk meningkatkan motorik halus dan mengembangkan imajinasinya, dan salah satu media yang biasa dipergunakan adalah media gambar. Ternyata media gambar dapat digunakan dalam proses pembelajaran di MI Ar Rahmah, melaui pengalaman yang langsung diperoleh di lapangan anak dapat mengikuti bentuk apa yang dilihatya, mengamati, mendapat informasi dan mengkaji segala sesuatu secara langsung. Pembelajaran yang didapat anak melalui media gambar sangat bervariasi. Anak belajar tentang kreatifitas, imajinasi, kedisiplinan, pemahaman, keterampilan dan juga kerapihan. Contohnya ketika anak mengikuti proses pembelajaran tentang menggambar keindahan alam yang ada di dunia yang menjelaskan bagaimana cara membuat gunumg, pantai, pohon-pohon dan lain-lain yang sering dilihat, maka anakpun akan lebih memahami dan belajar dengan imajinasinya yang dituangkan kedalam gambar. Dari kegiatan langsung yang dilakukan anak, rasa ingin tahu anak akan terjawab, anak bisa mengkaji sendiri pengalamannya. Eksplorasi yang dilakukan oleh anak terhadap pengalaman yang dialaminya merupakan proses belajar yang efektif.

Dari proses pembelajaran ini tidak terlepas dari peran guru sebagai seorang fasilitator dan juga motivator. Guru sebagai sumber belajar harus mempunyai kualifikasi dan kompetensi yang dapat menunjang proses pembelajaran untuk mencapai tujuan yang diinginkan. Sebagai seorang guru harus memahami karakteristik siswa, mampu mengidentifikasi potensi siswa, mampu mengidentifikasi kemampuan awal siswa, dan juga mampu mengidentifikasi kesulitan siswa dari siswa. Dalam proses pembelajaran dengan menggunakan 
media gambar ini guru harus bisa lebih kreatif dan menguasai materi pembelajaran yang akan diberikan, juga menguasai area atau tempat yang akan dijadikan pembelajaran, peran orang tua juga sangat dibutuhkan untuk kelancaran proses pembelajaran dengan media gambar ini, dengan cara memotivasi anak agar lebih semangat dan tidak mudah menyerah karena kebanyakan anak apabila sedang mengerjakan sesuatu dan di tengah kegiatan sudah merasa bosan dan kehabisan akal maka anak akan menyudahi kegiatannya tersebut.

\section{Faktor-faktor Pendukung Terhadap Penggunaan Media Gambar Untuk Meningkatkan Motorik Halus Pada Anak kelas 1 di MI Ar Rahmah}

Faktor pendukung adalah aspek yang sangat penting untuk membelajarkan anak. Tanpa adanya motivasi dari faktor pendukung, tidak mungkin anak memiliki kemauan untuk belajar. Oleh karena itu, membangkitkan motivasi merupakan salah satu peran dan tugas dari guru sebagai sumber belajar dalam setiap proses pembelajaran. Faktor pendukung sebagai motivasi dapat diartikan sebagai dorongan yang memungkinkan anak untuk bertindak atau melakukan sesuatu. Dorongan itu hanya mungkin muncul dalam diri anak manakala anak merasa membutuhkan. Anak yang merasa butuh akan bergerak dengan sendirinya untuk memenuhi kebutuhannya. Oleh sebab itu dalam rangka membangkitkan motivasi, guru harus dapat menunjukan pentingnya pengalaman dan materi belajar bagi kehidupan anak, dengan demikian anak akan belajar bukan hanya sekedar untuk memperoleh nilai atau pujian akan tetapi didorong oleh keinginan untuk memenuhi kebutuhannya.

Dalam proses pembelajaran dengan menggunakan media gambar ini, motivasi anak selaku siswa cukup tinggi. Keinginan anak untuk menembah kreatifitas, imajinasi, bersosialisasi dengan teman sebaya, melatih kesabaran juga kedisiplinan menjadi sebuah motivasi sendiri dalam mengikuti pembelajaran ini. Kesediaan dan minat anak ketika mengikuti pembelajaran media gambar terlihat begitu antusias, terutama ketika materi belajar yang mengenai gambar yaitu keindahan alam, anakanak diajak bereksplorasi tentang bagaimana menggambar bentuk gunung, apa warna yang cocok untuk masing-masing bentuk yang telah di gambarkan. Semua anak diajak melihat dan mengeksplorasi tentang bagaimana cara menuangkan yang 
ada di dalam imajinasi kedalam gambar dengan cara yang yang sederhana yang sudah dipersiapkan oleh guru sebelumnya, juga alat-alat yang selalu dipakai. Anak belajar tentang banyak hal, terutama memahami bahwa keindahan alam adalah Allah Swt yang menentukan.

Untuk memberikan faktor pendukung sebagai motivasi anak kelas 1 agar lebih antusias dalam menjalani proses pembelajaran dengan menggunakan media gambar, anak diberikan penghargaan berupa hal yang membuat anak lebih termotivasi lagi dalam pembelajaran.

Ada juga bentuk motivasi bagi anak yang guru gunakan dalam pembelajaran media gambar ini, contohnya memberikan hadiah berupa gambar bintang tersenyum untuk yang berhasil dan gambar bintang bersedih untuk yang belum berhasil. Ketika anak mendapatkan bintang tersenyaum anak senang sekali hingga ingin mengulangnya berkali-kali karena ingin mendapatkan bintang tersenyum kembali, sedangkan ketika anak mendapatkan bintang berseih terlihat anak berusaha keras untuk berhasil dalam proses pembelajaran dengan cara mengulang hingga mendapatkan bintang tersenyum. Bentuk motivasi lain yang dapat guru gunakan dalam proses pembalajaran ini yaitu dengan gerak tubuh. Gerakan tubuh dalam bentuk mimik yang cerah, dengan senyum, mengangguk, acungan jempol, tepuk tangan, memberikan salam, menaikan bahu, geleng-geleng kepala, menaikan tangan adalah sejumlah gerakan pisik yang dapat memberikan umpan balik dari anak didik. Gerakan tubuh merupakan penguatan yang dapat membangkitkan gairah belajar anak, hingga proses pembelajaran lebih menyenangkan. Pujian juga bisa dilakukan guru karena anak senang dipuji atas sesuatu hal yang dikerjakannya, pujian dapat dimanfaatkan sebagai faktor pendukung alat motivasi.

\section{Hasil Penggunaan Media Gambar Untuk Meningkatkan Motorik Halus Pada Anak kelas 1 di MI Ar Rahmah}

Kemampuan anak dalam mengikuti proses pembelajaran dengan menggunakan media gambar adalah kreatifitas. Anaknya memiliki kreatifitas dan imajinasi yang tinggi, sikap yang sangat diperlukan dalam proses pembelajaran dengan media gambar. Untuk kualifikasi dan kompetensi sumber belajar (guru), minimal lulusan S1 dan memiliki kualifikasi dalam menghadapi anak, mapu berkomunikasi secara 
aktip mampu menciptakan suasana permainan yang bervariasi, dan menguasai karakteristik anak dari semua aspek.

Dalam penyusunan materi pembelajaran yang diberikan oleh guru, pelaksanaannya berjalan baik dengan pihak penyelenggara dan pengelola yang menjadi penanggung jawab dari semua proses pembelajaran, tugas dari penyelenggara dan pengelola adalah merencanakan materi pembelajaran, mengawasi selama proses pembelajaran dengan menggunakan media gambar ini.

Materi pembelajaran dengan menggunakan media gambar yang diberikan oleh guru sangat beragam, terkadang dengan beraktivitas langsung ke lapangan menjadikan anak lebih memahami tentang banyak hal, antara lain :

a. Pengenalan tentang keindahan alam

b. Pengenalan tentang alat-alat yang digunakan untuk menggambar

c. Media gambar yang akan digunakan.

Selama mengikuti proses pembelajaran dengan media gambar ini, anak terlihat antusias dan aktip. Guru membimbing anaknya selama proses pembelajaran berlangsung, dan menjawab aktip disaat anaknya bertanya tentang materi yang dipraktekan. Pihak luar yang terkait dengan proses pembelajaran ini pun sangat mendukung dengan memberikan penjelasan tentang media gambar tersebut karena untuk meningkatkan motorik halus pada anak kelas 1 .

\section{PENUTUP}

Pendidikan bagi anak kelas 1 diberikan kepada anak agar dapat berkembang secara optimal. Mengingat pentingnya masa ini, meka peran stimulasi berupa penyediaan lingkungan dan alat-alat pembelajaran yang kondusif harus disiapkan oleh orang tua, guru, pengasuh atau orang dewasa lainnya yang ada disekitar anak, hingga anak memiliki kesmpatan untuk mengembangkan seluruh potensinya, meliputi aspek moral dan nilai-nilai agama, social, emosional, kemandirian, kemampuanberbahasa, kognitif, motoric dan seni.

Upaya pengembangan harus dilakukan melalui proses kegiatan belajar yang kreatif, edukatif, dan inovatif. Sehingga anak dapat bereksplorasi, menemukan dan mengekspresikan perasaannya. Belajar pada hakikatnya adalah aktivitas untuk 
melakukan perubahan tingkah lakunya pada ranah kognitif, afektip dan psikomotorik. Pembelajaran merupakan bentuk penyelenggaraan pendidikan yang memadukan secara sistematis dan berkesinambungan suatu kegiatan. Kegiatan pembelajaran dapat dilakukan di lingkungan kelas dan di luar lingkungan kelas dalam wujud penyediaan beragam pengalaman belajar untuk semua siswa.

Dalam proses pembelajaran dibutuhkan suatu media yang dapat mengimplementasikan rencana yang sudah disusun dalam kegiatan belajar, di MI Ar Rahmah media yang digunakandalam proses pembelajaran untuk meningkatkan motorik halus adalah media gambar. Media gambar adalah sebuah penyajian objek dalam bentuk gambar dapat disajikan melalui bentuk nyata maupun kreasi khayalan atau imajinasi yang sesuai dengan bentuk yang pernah dilihat oleh orang yang menggambarnya. Media gambar juga bisadiar tikan sebagai salah satu teknik mengajar yang dilakukan oleh seorang guru atau orang lain yang ditunjuk untuk memperlihatkan kepada kelas tentang suatu proses atau cara untuk mengenalkan sesuatu. Media gambar yang digunakan dalam proses pembelajaran di MI Ar Rahmah untuk melatih kreatifitas, imajinasi, kedisiplinan, kesabaran, sosialisasi, pemahaman, menambah wawasan, dan melatih motoric halus yang telah dimiliki oleh anak, dengan pembelajaran melalui pengalaman langsung dengan berkreativitas langsung dengan melakukan kefiatan yang akan diberikan kepada siswa.

Kemampuan anak dalam mengikuti proses pembelajaran dengan menggunakan media gambar adalah kreativitas. Anaknya memiliki keinginan dan ketertarikan yang tinggi, sikap yang sangat diperlukan dalam proses pembelajaran dengan media gambar. Untuk mencapai tujuan pembelajaran seperti yang dikemukakan diatas, diperlukan metode yang dapat mengembangkan kreativitas anak, mengembangkan bahasanya, emosi, motorik, dan juga pengembangan sikapnya. Media yang dipilih adalah media yang dapat menggerakan anak untuk meningkatkan motivasi rasa ingin tahu dan mengembangkan imajinasinya, dan salah satu media yang biasa digunakan adalah media gambar .ternyata media gambar dapat digunakan dalam proses pembelajaran di MI Ar Rahmah, melalui pengalaman yang langsung diperoleh di lapangan anak dapat mengobservasi, mengamati, mendapat, informasi 
dan mengkaji segala sesuatu secara langsung. Pembelajaran yang didapat anak melalui metdia gambar sangat beragam.Anak belajar tentang kreatifitas, imajinasi, kesenian, kedisiplinan, pemahaman, dan juga kesabaran.

\section{DAFTAR PUSTAKA}

Sadiman, Arief S dkk. 2006. Media Pendidikan Pengertian, Pengembangan, dan Pemanfaatannya. Raja Grafindo. Jakarta

Angkowo \& Kosasih. 2007. Optimalisasi Media Pembelajaran. Grasindo. Jakarta. Arif S. Sadiman. 2005. Media Pendidikan. Jakarta: Grafindo. 